\title{
Morphological Response of Jack Pine to the Interactive Effects of Carbon Dioxide, Soil Temperature and Photoperiod
}

\author{
Md. Shah Newaz', Qing-Lai Dang1*, Rongzhou Man² \\ ${ }^{1}$ Faculty of Natural Resources Management, Lakehead University, Thunder Bay, Canada \\ ${ }^{2}$ Ontario Ministry of Natural Resources, Ontario Forest Research Institute, Sault Ste. Marie, Canada \\ Email: *qdang@lakeheadu.ca
}

Received 13 March 2016; accepted 23 April 2016; published 26 April 2016

Copyright (C) 2016 by authors and Scientific Research Publishing Inc.

This work is licensed under the Creative Commons Attribution International License (CC BY).

http://creativecommons.org/licenses/by/4.0/

(c) (i) Open Access

\section{Abstract}

Responding to the predicted shift in climate envelope jack pine, (Pinus banksiana Lamb.) might migrate $10^{\circ}$ northward between 2071 and 2100 and will be exposed to a different photoperiod regime. Successful migration of the species might depend on the initial acclimating capability to the conditions of new location. The impacts of elevated carbon dioxide concentration [ $\mathrm{CO}_{2}$ ], soil temperature and photoperiod on the phenological traits, growth and biomass responses in jack pine seedlings were investigated. Seedlings were grown in greenhouses under two $\left[\mathrm{CO}_{2}\right][400$ and 950 $\mu \mathrm{mol} \cdot \mathrm{mol}^{-1}$ ), two soil temperatures (ambient soil temperature at seed origin and $5^{\circ} \mathrm{C}$ warmer) and three photoperiod regimes (photoperiods at seed origin, $5^{\circ}$ north of the seed origin and $10^{\circ}$ north of the seed origin). Budburst and bud setting time were recorded and the seedling height (Ht), root collar diameter (RCD), root biomass, stem biomass and leaf biomass were measured after six months of treatment. It was observed that under elevated $\left[\mathrm{CO}_{2}\right]$, ambient $\mathrm{T}_{\text {soil }}$ and photoperiods associated with $10^{\circ}$ northward migrations budburstis advanced by 10 days. Photoperiods toward north significantly prolonged the bud setting time. However, tri-factor interactive effect on bud set was not statistically significant. Elevated $\left[\mathrm{CO}_{2}\right]$ significantly $(\mathrm{P}<0.05)$ increased the $\mathrm{RCD}$, volume of the seedlings and total biomass and longer growing season photoperiods towards north significantly increased the seedling heights. Though elevated $\left[\mathrm{CO}_{2}\right]$ significantly increased the projected leaf area, it had no significant effect on specific leaf area. Elevated $\left[\mathrm{CO}_{2}\right]$ significantly reduced the shoot to root ratio, which indicated higher biomass allocation in roots under elevated $\left[\mathrm{CO}_{2}\right]$. However, all these growth and biomass responses were statistically insignificant under tri-factor interactive effects. The results suggest that climate change induced northward migration will not affect the growth of jack pine. However, a long distance migration (e.g. $10^{\circ}$ north) will expose the species to late-spring frost damage.

\footnotetext{
"Corresponding author.
} 


\section{Keywords}

\section{Tree Seedling Physiology, Plant Ecophysiology, Tree Migration, Climate Change, Boreal Forest}

\section{Introduction}

Phenological sensitivity reflects the ability of a species to track climate change and indicates whether the species will persist or decline in response to climate changes [1]. Phenological events are easily observable and most sensitive traits to climate change [2]. Plants responded to changes in growing conditions and altered availability of resources induced by climate change by making phenotypic and physiological adjustments, or by migrating to a new area having similar environmental conditions that they are adapted to, or by combinations of the above responses and eventually by genetically adapting to the new conditions [3]. Historical evidence indicates that all the above mechanisms have occurred in plants' responses to climate change [4]. During the process of migration and adaptation plants encounter multiple challenges. Since it is almost impossible to get exactly the same environmental conditions to migrate to, plants usually migrate to a relatively favorable site and phenotypic plasticity plays a critical role in the success of such a migration. Phenotypically, plastic changes have a large influence on the immediate fate of the migrating plants via their effects on survival and reproduction [5].

Each environmental factor such as atmospheric carbon dioxide concentration $\left[\mathrm{CO}_{2}\right]$, temperature and photoperiod has its own impacts on the growth and biomass allocations in trees [6]-[8]. Increased atmospheric $\left[\mathrm{CO}_{2}\right]$ generally increases the photosynthetic capacity of plants leading to an increased carbon balance, growth and yield [9]-[14] because of increased photosynthetic carbon acquisition and changes in biomass allocation [15]. Elevated $\left[\mathrm{CO}_{2}\right]$ can markedly alter the structure and physiology of plants, such as increased leaf expansion and cell wall extensibility and often cell turgor pressure, leading to increased leaf and root growth. Increased atmospheric $\left[\mathrm{CO}_{2}\right]$ can increase total leaf area [16], leaf mass [17], leaf mass to area ratio [18], and branching frequency [19]. Elevated atmospheric $\left[\mathrm{CO}_{2}\right]$ enhances root growth [10] [20] and affects many important root traits [21]. Root biomass, root length, root branching and lateral root production are reported to increase in response to elevated $\left[\mathrm{CO}_{2}\right][20]$ [22] [23]. Elevated $\left[\mathrm{CO}_{2}\right]$ can affect the growth rhythm of trees by altering the timing of bud burst and growth cessation and results in an increased seedling cold tolerance in early fall [24] [25]. It can significantly advance the date of bud burst and increase total foliage area as a result of increased number and length of shoots and increased individual foliage area [26]. Early bud burst, however, may increase the risk of frost damage from late spring frosts [27].

Soil temperature influences the growth and physiology in plants, such as biomass allocation, shoot and root growth, stomatal conductance and nutrient and water uptake [7] [28]-[34]. The soil temperature in the boreal forest is often too low for the optimal physiological activities and growth [35]. For example, low soil temperature can inhibit nutrient and water uptake, limit shoot growth [36] [37] and reduce photosynthetic productivity [38]. Therefore, the increase of soil temperature by climatic warming would be beneficial to boreal plants [30] [39] [40]. Warmer soil temperatures improve water uptake, root growth and root permeability [41].

Photoperiod regulates annual growth cycles in temperate and boreal trees and influences their geographic distribution [42]-[45]. Plants are generally adapted to the photoperiod regime of their habitats over hundreds and thousands of years [46]. Photoperiod regulates the development of cold hardness in the fall and the timing of bud flush in the spring [2] [47] [48]. However, photoperiod is not considered in climate envelop models. If species immigrate naturally or with human assistance based on the shift of their climate envelopes, it is possible that the species may not be able to acclimate to the photoperiod regimes at their new location.

Although the individual effects of elevated atmospheric $\left[\mathrm{CO}_{2}\right]$, warmer soil temperature and prolonged photoperiod on plant growth are mostly positive, their combined effects may not be equal to the sum of the individual effects [49] [50]. Soil temperature and light regime influence the responses of plants to elevated $\left[\mathrm{CO}_{2}\right][12]$ [51]-[54]. However, elevated $\left[\mathrm{CO}_{2}\right]$ in combination with increased temperature have no significant effect on the overall height growth of jack pine seedlings, but significantly increase the total biomass [55]. Cantin et al. (1997) [55] report that the growth of jack pine seedlings under elevated $\left[\mathrm{CO}_{2}\right]$ and temperature results in reduced leaf mass ratio as more biomass is allocated to roots. The effects of individual environmental factors or bi-factor effects on boreal tree growth are well documented [2] [37] [56]-[60], but the understanding of interactive effects 
of multiple environmental variables such as $\left[\mathrm{CO}_{2}\right]$, soil temperature and photoperiod, on boreal tree growth is still limited.

Jack pine (Pinus banksiana Lamb.) is a major tree species in the boreal forests of Canada holding great ecological and commercial values and thus deserves special attention in the context of climate change. Jack pine is the second most planted tree species in Canada after black spruce [61] [62]. In Ontario jack pine comprises approximately 37\% of the total annual softwood harvest [63]. Atmosphere Ocean General Circulation Models predict a 10 degree (approximately 1000 kilometers) northward shifts in the climate envelopes of 130 North American tree species between 2071 and 2100 [64] [65]. Following the predicted shift in climate envelopes jack pine might need to migrate $10^{\circ}$ northward between 2071 and 2100 [66]. In that case, the species will be exposed to a different photoperiod regime, e.g. the photoperiods will be longer in the summer and shorter in the winter with faster transition between seasons than the regimes that it has adapted to, which might affect the phenological events of the species. But, the impacts of changes in photoperiod regimes associated with migration or seed transfer of jack pine are not yet well documented. Since the impacts of elevated atmospheric $\left[\mathrm{CO}_{2}\right]$ and warmer soil temperature on the growth of jack pine are mostly positive [33] [55] [67] while autumn leaf senescence and cold hardening are predominantly controlled by photoperiod [2] [48] and the time period for cold hardening becomes shorter because of the faster rate of photoperiod declines in the fall at higher latitudes, we hypothesize that elevated $\left[\mathrm{CO}_{2}\right]$ and soil temperature and photoperiods associated with northward migration or seed transfer will enhance the growth performance of jack pine but reduce the cold hardness. The overall objective of this study was to assess the interactive effects of photoperiod, soil temperature and $\mathrm{CO}_{2}$ elevation on the morphological traits of jack pine in the context of northward migration. The specific objectives of the study were to: 1) assess the tri-factor effects on the phenological traits of jack pine seedlings, 2) assess the impacts of elevated $\left[\mathrm{CO}_{2}\right]$, soil temperature and photoperiod on the growth performance and biomass allocation patterns and 3) investigate the spatial extent of possible northward migration following the predicted shift in climate envelope.

\section{Materials and Methods}

\subsection{Plant Materials}

One-year-old jack pine (Pinus banksiana Lamb.) seedlings were obtained from a commercial tree seedling nursery. The seedlings were raised from seeds collected from Kakabeka region $\left(48^{\circ} 57^{\prime} \mathrm{N} \& 90^{\circ} 44^{\prime} \mathrm{W}\right)$. A total of 608 seedlings of relatively uniform size (average height 13.05; averageroot collar diameter $0.21 \mathrm{~cm}$ ) were planted in plastic pots of size $15 \mathrm{~cm}$ in height and $13 \mathrm{~cm}$ in diameter, filled up with a mixture of premium grade vermiculite and peat moss $(50: 50, \mathrm{v} / \mathrm{v})$.

\subsection{Experimental Design}

The experiment was set on November 20, 2013 and continued until May 31, 2014 mimicking the actual day lengths and temperatures for the period of April 16 to October 31 (Table 1).

The experiment was conducted in four green houses at Lakehead University's Thunder Bay campus. The treatments were consisted of two levels of $\left[\mathrm{CO}_{2}\right]\left(400\right.$ and $\left.950 \mu \mathrm{mol} \cdot \mathrm{mol}^{-1}\right)$, two soil temperatures (the average soil temperature at seed origin $\left(\mathrm{T}_{\mathrm{s}}\right)$ and $5^{\circ} \mathrm{C}$ warmer $\left.\left(\mathrm{T}_{\mathrm{e}}\right)\right)$ and three photoperiod regimes $\left(\mathrm{P}_{\mathrm{s}}, \mathrm{P}_{\mathrm{nm} 1}\right.$ and $\mathrm{P}_{\mathrm{nm} 2}$, indicating photoperiods at seed origin, at $5^{\circ}$ north of the seed origin and $10^{\circ}$ north of the seed origin, respectively). The $10^{\circ}$ north of the seed origin represents the predicted northward shift of the climate envelopes for boreal tree species [64] [65] and the $5^{\circ}$ north is the midpoint between the current and the predicted future location of the species. The soil temperature of seed origin was derived from the biweekly mean soil temperature of the years 2012 and 2013 at Kakabeka region. Average temperatures at $5 \mathrm{~cm}$ and $20 \mathrm{~cm}$ soil depths were used in the experiment. Based on the biweekly average, soil temperatures were adjusted periodically. The experiment was carried out following a split plot design, with $\left[\mathrm{CO}_{2}\right]$ as the whole plot, soil temperature as the sub-plot and photoperiod as the sub-sub plot. Two levels of $\left[\mathrm{CO}_{2}\right]$ were randomly assigned to four independent greenhouses with two replicates of each. The two levels of soil temperature were duplicated within each level of $\left[\mathrm{CO}_{2}\right]$ and then three levels of photoperiod were nested within each soil temperature.

\subsection{Environmental Controls}

To elevate $\left[\mathrm{CO}_{2}\right]$ in the greenhouses, electronic ignition natural gas $\mathrm{CO}_{2}$ generators (model GEN-2E, Custom 
Table 1. Biweekly mean day length and mean air and soil temperature for the period of April 16 to October 31 . Air temperature is based on 10 years average (2004-2013). Soil temperatures are biweekly averages of soil temperatures at 5 and 20 cm depths in 2012 and 2013.

\begin{tabular}{|c|c|c|c|c|c|c|c|}
\hline \multirow{2}{*}{$\begin{array}{l}\text { Actual time } \\
\text { period }\end{array}$} & \multirow{2}{*}{$\begin{array}{l}\text { Experiment time } \\
\text { period }\end{array}$} & \multicolumn{3}{|c|}{ Mean day length (hours) } & \multicolumn{2}{|c|}{$\begin{array}{l}\text { Mean air temperature } \\
\left({ }^{\circ} \mathrm{C}\right) \text { at seed origin }\end{array}$} & \multirow{2}{*}{$\begin{array}{c}\text { Soil temperature } \\
\left({ }^{\circ} \mathrm{C}\right)\end{array}$} \\
\hline & & $\mathrm{P}_{\mathrm{s}}$ & $\mathrm{P}_{\mathrm{nm} 1}$ & $\mathrm{P}_{\mathrm{nm} 2}$ & Day & Night & \\
\hline Apr. 16-30 & Nov. 20-30 & 14.14 & 14.56 & 15.11 & 8 & 1 & 3 \\
\hline May 01-15 & Dec. 01-15 & 14.91 & 15.50 & 16.29 & 10 & 4 & 7 \\
\hline May 16-31 & Dec. 16-31 & 15.56 & 16.32 & 17.35 & 14 & 7 & 9 \\
\hline Jun. 01-15 & Jan. 01-15 & 15.98 & 16.85 & 18.08 & 17 & 9 & 12 \\
\hline Jun. 16-30 & Jan. 16-31 & 16.08 & 16.98 & 18.26 & 20 & 12 & 14 \\
\hline Jul. 01-15 & Feb. 01-14 & 15.87 & 16.72 & 17.89 & 22 & 14 & 16 \\
\hline Jul. 16-31 & Feb. 15-28 & 15.38 & 16.08 & 17.04 & 22 & 14 & 16 \\
\hline Aug. 01-15 & Mar. 01-15 & 14.68 & 15.21 & 15.93 & 22 & 14 & 15 \\
\hline Aug. 16-31 & Mar. 16-31 & 13.86 & 14.22 & 14.68 & 21 & 13 & 15 \\
\hline Sep. 01-15 & Apr. 01-15 & 12.98 & 13.16 & 13.40 & 18 & 11 & 13 \\
\hline Sep. 16-30 & Apr. 16-30 & 12.11 & 12.12 & 12.13 & 14 & 8 & 10 \\
\hline Oct. $01-15$ & May 01-15 & 11.24 & 11.08 & 10.87 & 12 & 5 & 8 \\
\hline Oct. 16-31 & May 16-31 & 10.36 & 10.02 & 9.58 & 7 & 2 & 6 \\
\hline
\end{tabular}

Note: $\mathrm{P}_{\mathrm{s}}, \mathrm{P}_{\mathrm{nm} 1} \& \mathrm{P}_{\mathrm{nm} 2}$ represent the seed origin, $5^{\circ}$ north of seed origin \& $10^{\circ}$ north of seed origin, respectively.

Automated Products Inc, Riverside, CA) were used. Circulation fans were used to make the air composition even throughout the greenhouse. The $\left[\mathrm{CO}_{2}\right]$ in each greenhouse was monitored and controlled automatically with an Argus Environment Control System (Argus, Vancouver, BC, Canada). The soil temperatures were controlled using a soil temperature control system consisting of a large leak-proof wooden box (196 cm long, 112 $\mathrm{cm}$ wide and $16 \mathrm{~cm}$ deep) designed by Cheng et al. (2000) [68]. The seedling containers were mounted within the soil temperature control box and temperature-controlled water was circulated in the space between the containers to maintain the desired soil temperature. To ensure the even distribution of temperature within the system, each control unit was equipped with circulatory pumps (model AC-2CP-MD, March Mfg. Inc., Glenview, Illinois, USA). The system was insulated to minimize heat exchange with the greenhouse air. Each day-time soil temperature was lowered by approximately $4^{\circ} \mathrm{C}-6^{\circ} \mathrm{C}$ at night to cater for lower night temperature. The lengths of the photoperiod for active growing and cold hardening phases for each of the three locations were set periodically based on the actual biweekly average photoperiods during the growing season and cold hardening phase at corresponding locations. Each photoperiod treatment was started with summer long days followed by the corresponding short days. The length of the natural photoperiod was extended using high-pressure sodium lamps when natural day lengths were shorter than the set photoperiods. Photoperiods shorter than the natural day length were achieved through manual shading of the seedlings in the early mornings and late evenings following standard blackout techniques used in tree nurseries. All the seedlings were fertilized biweekly with N:P:K fertilizer (7.14, 0.56 and $2.12 \mathrm{mmol}$ per liter of water, respectively during the rapid growth phase and 1.78, 2.20 and $4.64 \mathrm{mmol}$ per liter of water, respectively during the hardening phase) [69]. The moisture level was maintained at $60 \%-70 \%$ of the field water capacity. The moisture content of the growing medium was monitored daily using a Delta-T ML2x probe and HH2 moisture meter (Delta-T Devices, Cambridge, UK). In all the greenhouses the relative humidity was maintained at 55\% - 60\% during the rapid growth phase and reduced to $45 \%$ - 50\% during the hardening phase. The day and night air temperatures were maintained mimicking the mean biweekly day and night air temperatures at the seed origin. Relative humidity and air temperature were controlled automatically using the Argus Environment Control System. 


\subsection{Measurements}

Height and root collar diameter (RCD) of each individual seedling were measured at the beginning of the experiment. Ten seedlings from each treatment combination were randomly chosen to investigate bud break at the beginning and bud setting during the cold hardening phase. Bud break was determined by visual observation of the terminal meristem of seedlings. Bud break was considered completed when bud scales were mostly fallen, with tips of needles protruding about $2 \mathrm{~mm}$ [24]. Days to bud break was counted from the date of starting the treatment (November 20, 2013). Bud set was also determined by visual observation and it was considered accomplished when bud scales were completely closed [24]. Bud setting time was counted from April 16, 2014, when the day length and day and night air temperature were reduced to 12 hours and $14^{\circ} \mathrm{C}$ and $8^{\circ} \mathrm{C}$, respectively.

Heights and RCDs of three randomly chosen seedlings from each treatment combination were measured on May 28, 2014. The seedlings were then separated into foliage, stem (including branches) and roots. The needles were scanned with WinSeedle system (Regent Instruments Inc, Quebec, Canada) to determine the projected leaf area. The roots were scanned to analyze root traits using a WinRhizo system (Regent Instruments Inc, Quebec, Canada). The foliage, stem and roots were subsequently oven-dried at $70^{\circ} \mathrm{C}$ for 48 hours and weighed on an analytical balance $(0.001 \mathrm{~g}$ precision) to determine the dry mass. Stem mass ratio (ratio of stem mass to total biomass, SMR), root mass ratio (ratio of root mass to total biomass, RMR), leaf mass ratio (ratio of leaf mass to total biomass, LMR), shoot to root mass ratio (ratio of above ground to belowground mass, SRR) were used as indices of biomass allocation. Specific leaf area (SLA) was determined from the projected leaf area and leaf dry mass. Specific root length (SRL) and specific root surface area (SRA) were determined as root length per unit root dry mass and root surface area per unit root dry mass, respectively. Root length to leaf area ratio (RLA) was calculated to estimate the water supply/demand index. The stem Volume (V) was calculated from height $(\mathrm{H})$ and RCD (D) using the equation [70]: $\mathrm{V}=\left(\pi \mathrm{D}^{2} / 4\right) \mathrm{H} / 3$. The relative growth rate of height (HT), root-collar diameter (RCD) and Volume (Vol) were determined by dividing the increment by the corresponding initial measurement.

\subsection{Statistical Analysis}

All data were analyzed using Analysis of Variance (ANOVA). Before the ANOVA test, Shapiro-Wilk and Bartlett tests were conducted to test the normality of distribution and homogeneity of variance, respectively. Whenever necessary, suitable transformation was done to normalize the data. Tukey's HSD Post-hoc comparisons were carried out when ANOVA showed a significant interaction $(\mathrm{P}<0.05)$. In the analyses, $\left[\mathrm{CO}_{2}\right]$, soil temperature and photoperiod were treated as fixed factors. All analyses were done using R 3.1.3 [71].

\section{Results}

On the average, budburst advanced for 5 days by elevated $\left[\mathrm{CO}_{2}\right]\left(\mathrm{C}_{\mathrm{e}}\right)$ and 2 days by warmer soil temperature $\left(\mathrm{T}_{\mathrm{e}}\right)$ compared to those in current $\left[\mathrm{CO}_{2}\right](\mathrm{Ca})$ and soil temperature $\left(\mathrm{T}_{\mathrm{s}}\right)$ (Figure 1(a) and Figure 1(b)). The effect of soil temperature was mostly in $\mathrm{C}_{\mathrm{e}}$ (significant CxT interaction $(\mathrm{P}<0.05)$ see Table 1 and Figure $1(\mathrm{~d})$ ). The total day to budburst was significantly less with the photoperiod regimes associated with northward migration: $34.63 \pm 0.55,32.63 \pm 0.55$ and $29.69 \pm 0.49$ days for $\mathrm{P}_{\mathrm{s}}, \mathrm{P}_{\mathrm{nm} 1}$ and $\mathrm{P}_{\mathrm{nm} 2}$, respectively (Figure 1 (c)). The examination of the 3-way interaction ( $\mathrm{P}<0.05$ ) indicated the longest days to budburst for $\mathrm{C}_{\mathrm{a}} \times \mathrm{T}_{\mathrm{s}} \times \mathrm{P}_{\mathrm{s}}$ treatment combination (38.7 \pm 0.874$)$ and the shortest for $\mathrm{C}_{\mathrm{e}} \times \mathrm{T}_{\mathrm{e}} \times \mathrm{P}_{\mathrm{nm} 2}$ combination (25.7 \pm 0.7$)$ (Figure $1(\mathrm{e})$ ). The total day to bud setincreased with photoperiod $\left(\mathrm{P}_{\mathrm{s}}\right)$ from $\mathrm{P}_{\mathrm{s}}\left(32.16 \pm 0.2\right.$ days) to $\mathrm{P}_{\mathrm{nm} 2}$ (34.58 \pm 0.157 days) $(\mathrm{p}<0.001$, Figure $1(f))$ and the variation among $C_{a} \times T_{e}$ within $P_{s}$ was marginally significant effect $(p=0.087)$.

The relative growth rate of height $\left(\mathrm{RGR}_{\mathrm{H}}\right)$ increased $(\mathrm{P}<0.05)$ with the length of photoperiod $(1.24 \pm 0.04$ for $\mathrm{P}_{\mathrm{nm} 2}$ vs. $1.12 \pm 0.03$ for $\mathrm{P}_{\mathrm{s}}$, Figure 2(a)). Similarly, the relative growth rate of RCD (RGR $\mathrm{D}_{\mathrm{D}}$ ), relative growth rate of stem volume growth $\left(\mathrm{RGR}_{\mathrm{V}}\right)$, and seedling total biomass $(\mathrm{M})$ became greater by elevated $\left[\mathrm{CO}_{2}\right]$ (Figure 2(b), Figure 2(d), Figure 2(e)). The significant CxT interaction $(\mathrm{P}<0.05)$ on $\mathrm{RGR}_{\mathrm{D}}$ indicated greater $\left[\mathrm{CO}_{2}\right]$ effect under current soil temperature (see Table 2, Figure 2(c)).

The biomass allocation of jack pine seedlings was significantly affected by atmospheric $\left[\mathrm{CO}_{2}\right]$ and soil temperature ( $\mathrm{P}<0.05$, Table 2). The total projected leaf area was significantly greater (Figure 3(a)), and leaf mass ratio $(0.34 \pm 0.00$ vs. and $0.29 \pm 0.00$ ), shoot to root mass ratio (1.56 \pm 0.05 vs. $1.31 \pm 0.04)$ (Figure 3(b) and Figure 3(c)), specific root length (10.57 \pm 0.38 vs. $7.35 \pm 0.15 \mathrm{~m} / \mathrm{gm}$, and specific root area (219.63 \pm 6.02 vs. $159.29 \pm 4.52 \mathrm{~cm}^{2} / \mathrm{gm}$ ) (Figure 3(d) \& Figure 3(e)) were smaller under elevated $\left[\mathrm{CO}_{2}\right]$. The root length to leaf 


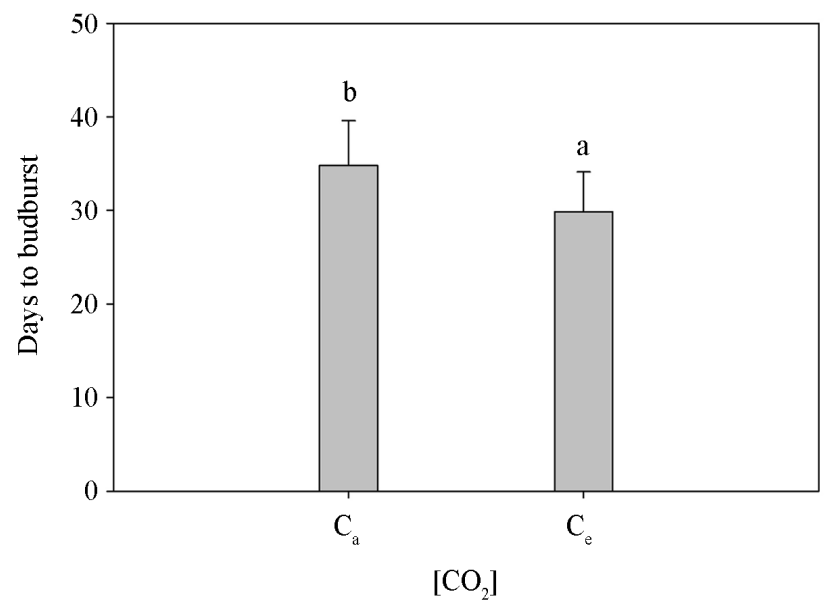

(a)

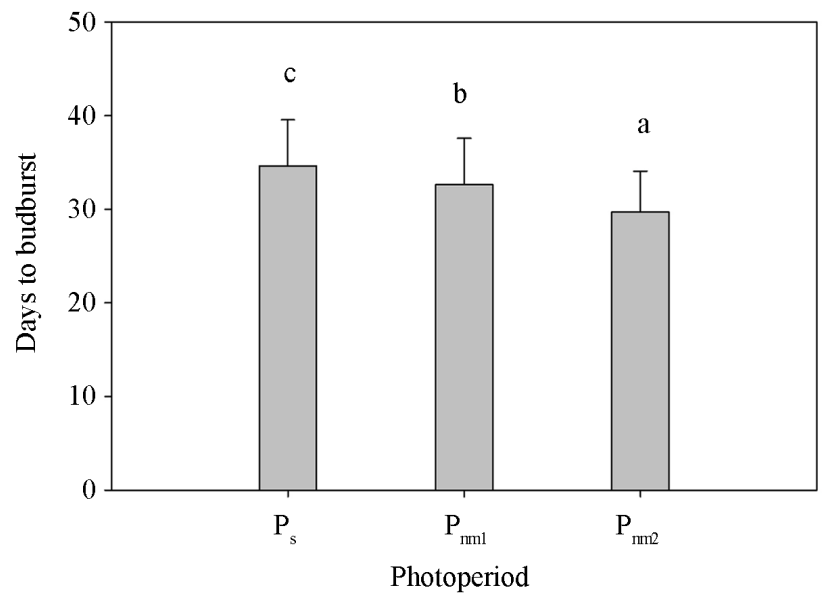

(c)

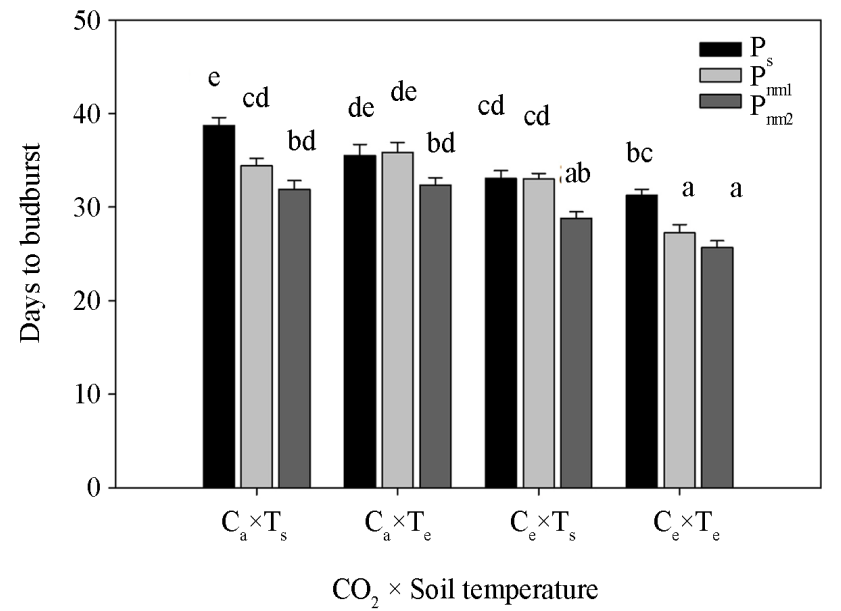

(e)

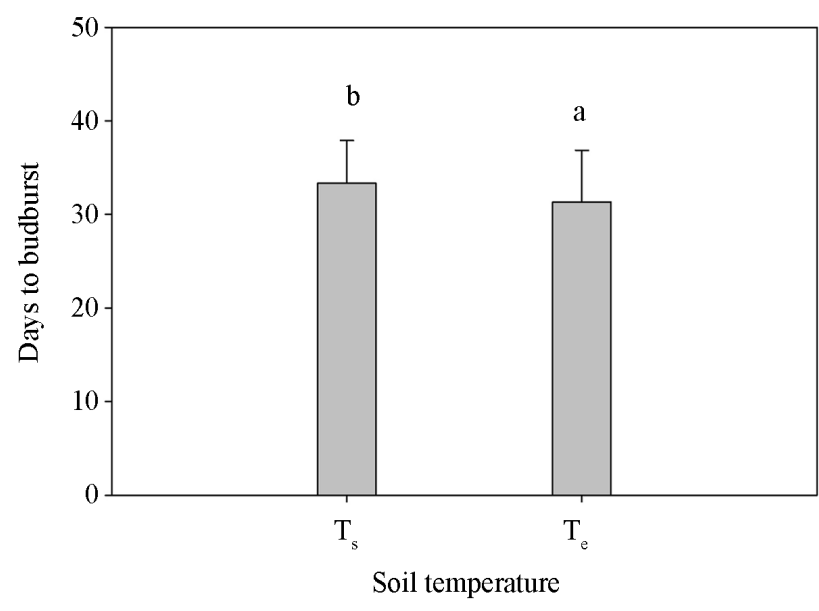

(b)

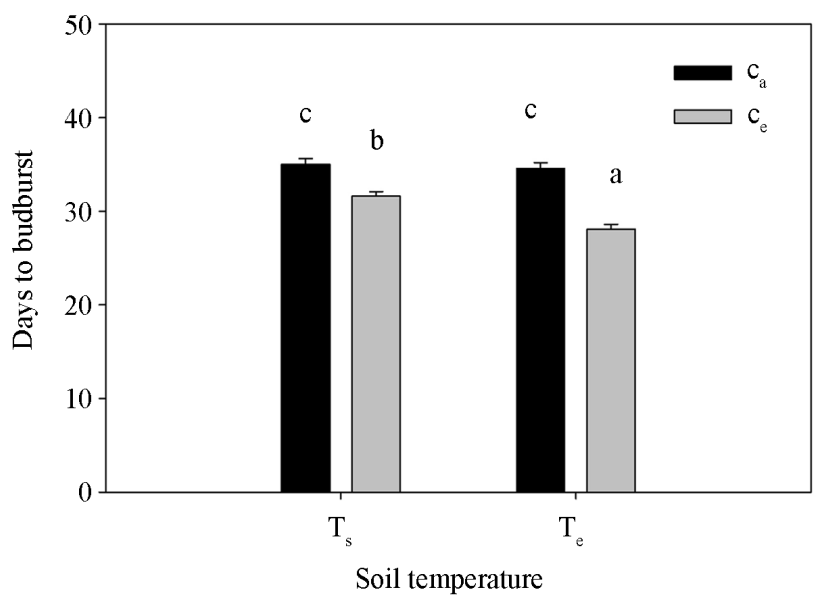

(d)

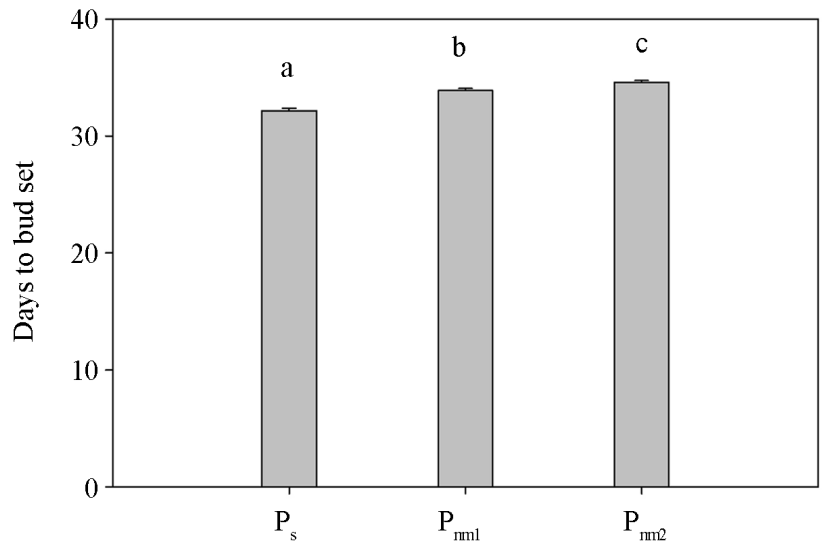

Photoperiod

(f)

Figure 1. Least square means (+SE) of total days to budburst and bud set in jack pine seedlings grown under two levels of [CO $\left.{ }_{2}\right]$ $\left(C_{a}=400 \& C_{e}=950 \mu \mathrm{mol} \cdot \mathrm{mol}^{-1}\right)$, two soil temperature $\left(T_{s}\right.$, seed origin and $T_{e}, 5^{\circ}$ warmer than $\left.T_{s}\right)$ and three photoperiods $\left(P_{s}\right.$, seed origin and $\mathrm{P}_{\mathrm{nm} 1}$ and $\mathrm{P}_{\mathrm{nm} 2}$, values for $5^{\circ} \& 10^{\circ}$ northward migration, respectively). Different lowercase letters indicate statistically significant differences at $\mathrm{P} \leq 0.05$. 


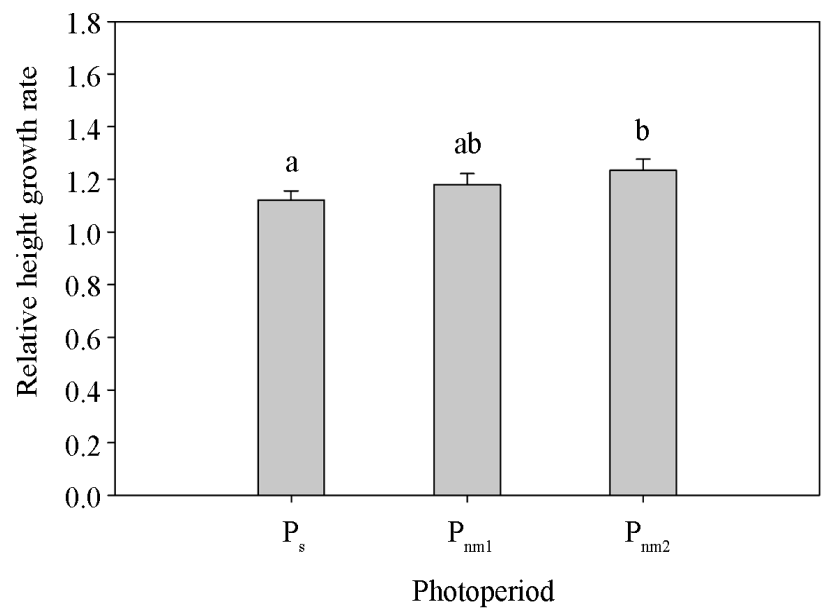

(a)

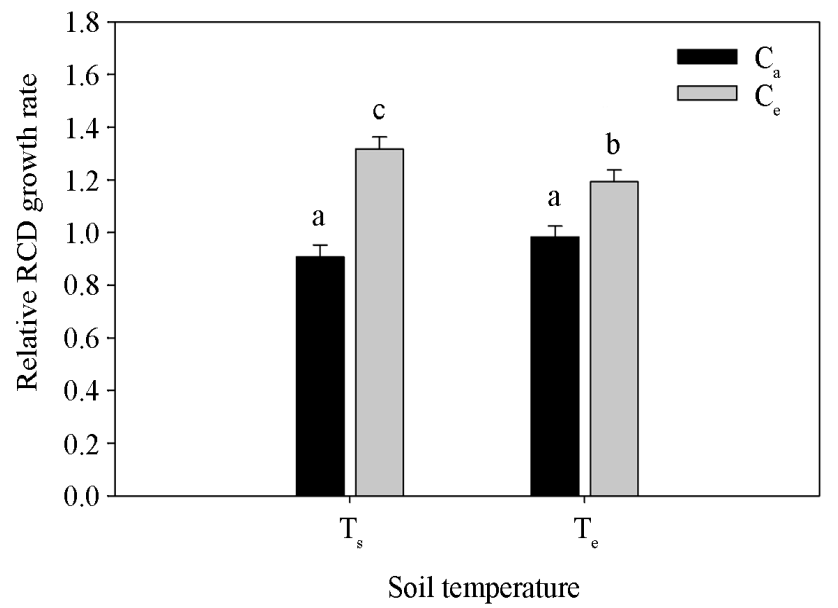

(c)

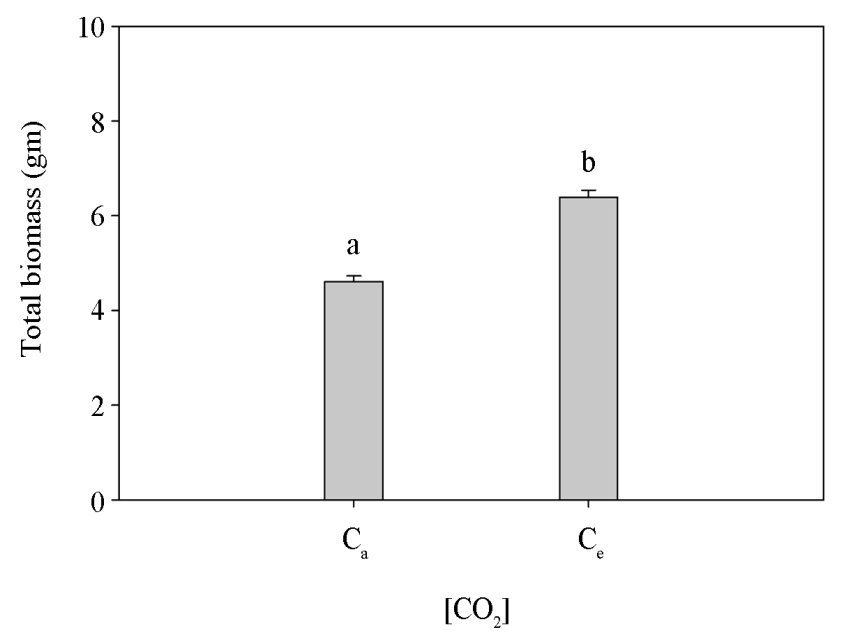

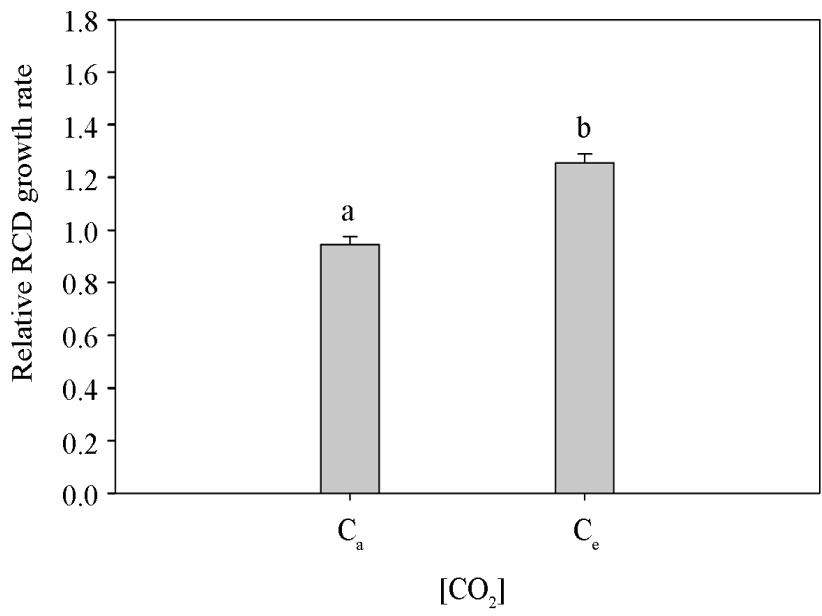

(b)

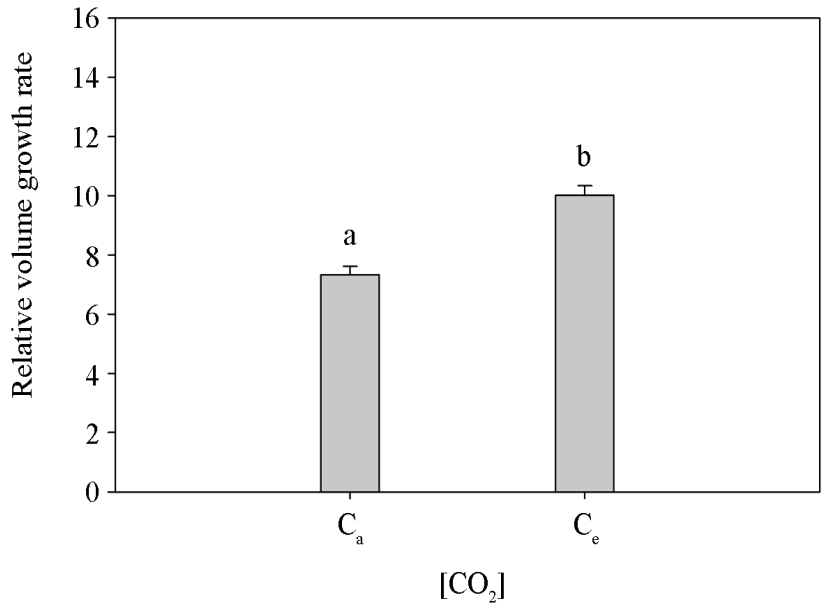

(d)

(e)

Figure 2. Least square means (+SE) of relative growth rates for height, root collar diameter (RCD) and stem volume, and total seedling biomass in jack pine seedlings grown under two levels of $\left[\mathrm{CO}_{2}\right]\left(\mathrm{C}_{a} \& \mathrm{C}_{e}\right)$, two soil temperature $\left(\mathrm{T}_{\mathrm{s}} \& \mathrm{~T}_{\mathrm{e}}\right)$ and three photoperiods $\left(\mathrm{P}_{\mathrm{s}}, \mathrm{P}_{\mathrm{nm} 1} \& \mathrm{P}_{\mathrm{nm} 2}\right)$. Different lowercase letters indicate statistically significant differences at $\mathrm{P} \leq 0.05$. 


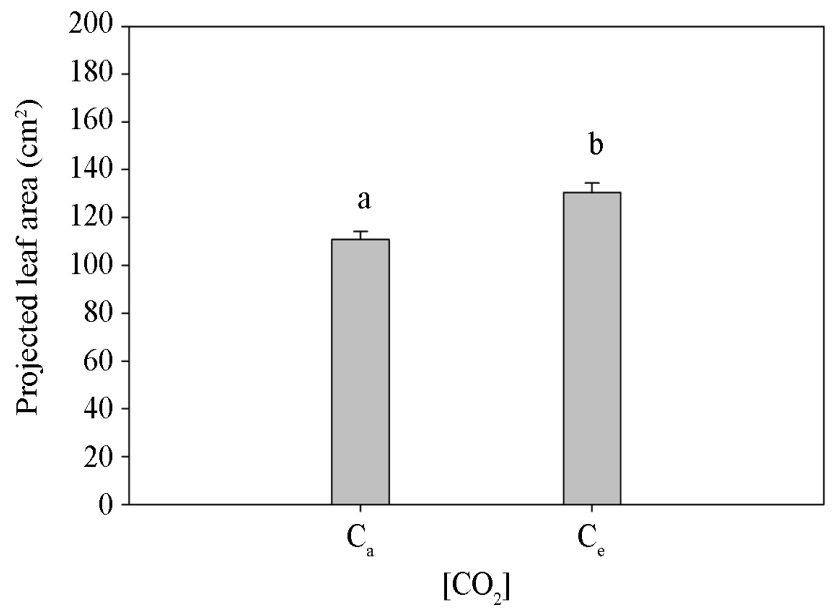

(a)

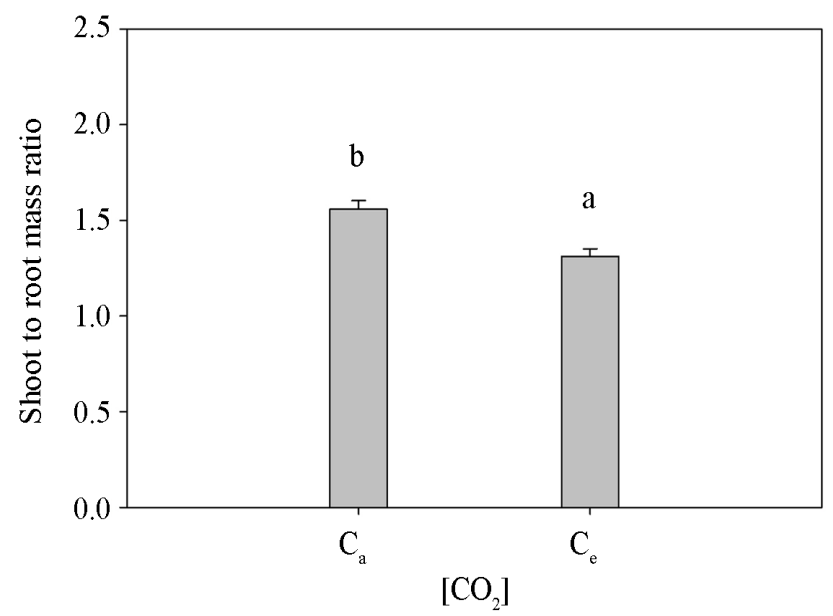

(c)

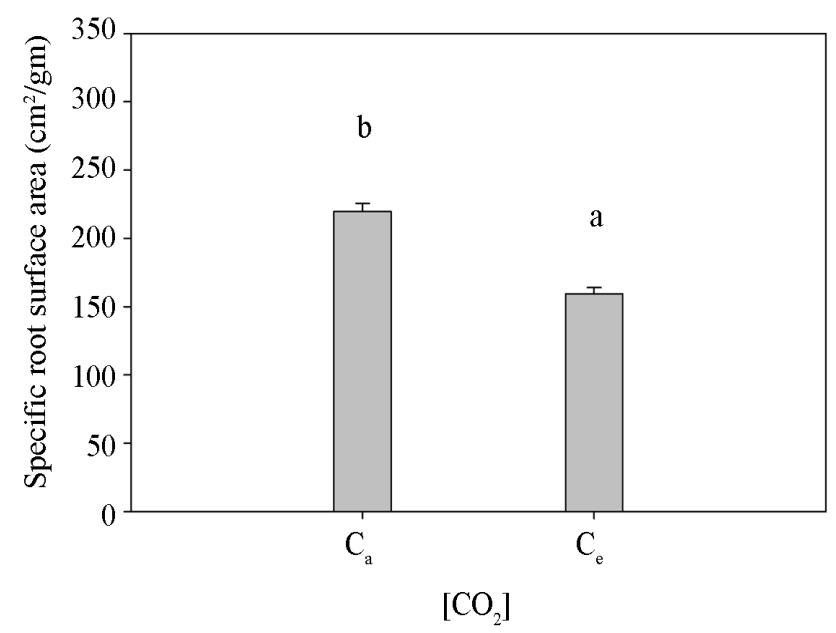

(e)

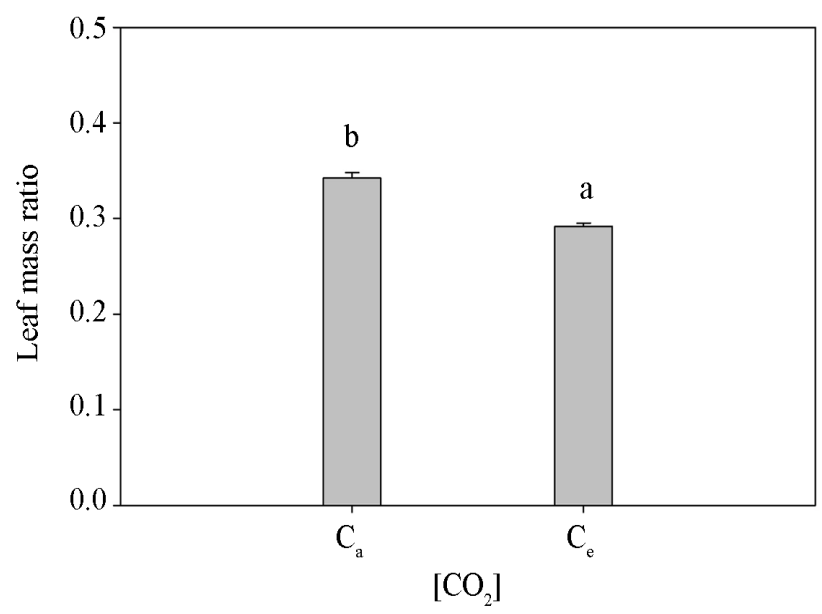

(b)

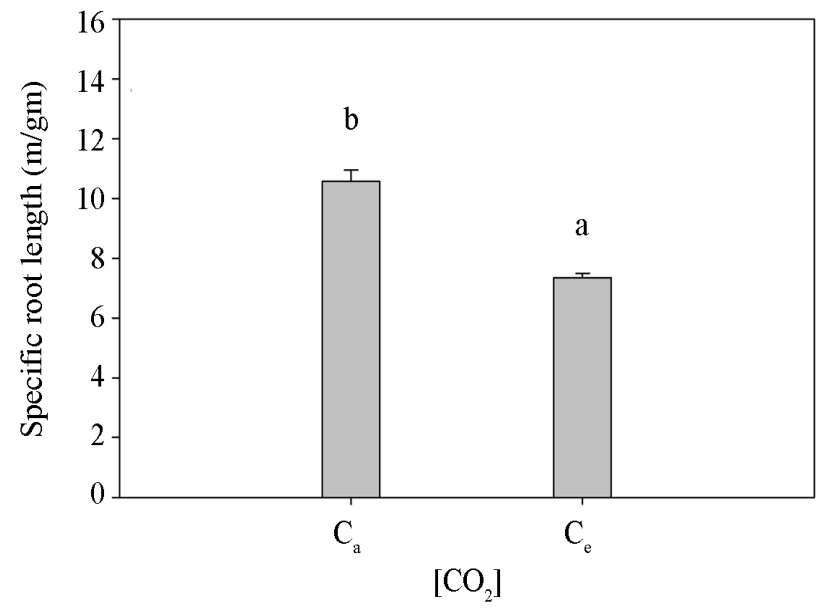

(d)

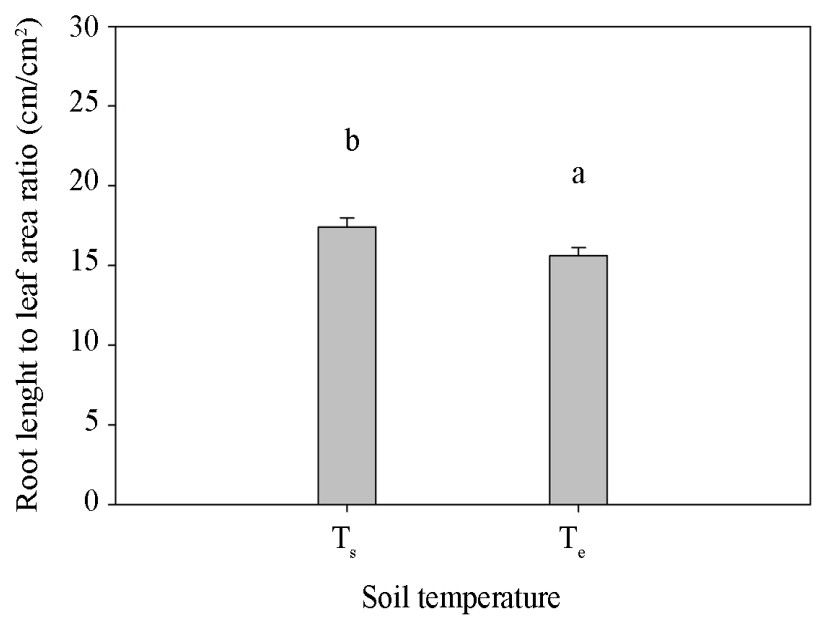

(f)

Figure 3. Least square means (+SE) of total leaf area, leaf mass ratio, shoot to root mass ratio, specific root length, specific root surface area and root length to leaf area ratio in jack pine seedlings grown under two levels of $\left[\mathrm{CO}_{2}\right]\left(\mathrm{C}_{\mathrm{a}} \& \mathrm{C}_{\mathrm{e}}\right)$, two soil temperature $\left(\mathrm{T}_{\mathrm{s}} \& \mathrm{~T}_{\mathrm{e}}\right)$ and three photoperiods $\left(\mathrm{P}_{\mathrm{s}}, \mathrm{P}_{\mathrm{nm} 1} \& \mathrm{P}_{\mathrm{nm} 2}\right)$. Different lowercase letters indicate statistically significant differences at $\mathrm{P} \leq$ 0.05 . 
area ratio reduced with the increase of soil temperature $\left(15.59 \pm 0.52\right.$ vs. $17.41 \pm 0.57 \mathrm{~cm} / \mathrm{cm}^{2}$, Table 2, Figure $3(\mathrm{f}))$.

\section{Discussions}

The advance of budburst in jack pine seedlings with $\left[\mathrm{CO}_{2}\right]$ elevation, soil temperature warming and photoperiod increase is consistent with the results of many predictions [72]-[80], but different from others including delayed or no responses to elevated $\left[\mathrm{CO}_{2}\right]$ [24] [81]-[85] and to elevated soil temperature on various tree species [86][89]. As budburst is primarily controlled by temperature and longer photoperiod promotes dormancy release and budburst only in some species [73] [74] [76] [78]-[80] [90] [91], the advance of budburst by $\mathrm{P}_{\mathrm{nm} 2}$ may be more due to the greater thermal accumulation under longer daytime hours in spring time. The individual effects of elevated $\left[\mathrm{CO}_{2}\right]$, soil temperature and longer growing season photoperiods appeared to be additive; the budburst in the $C_{e} \times T_{e} \times P_{n m 2}$ combination was 13 days earlier than that in the $C_{a} \times T_{s} \times P_{s}$ treatment combination. Advances in budburst will likely increase the risk of spring frosts, which may be an obstacle to the northward migration of jack pine.

The lack of treatment effect by $\left[\mathrm{CO}_{2}\right]$ and soil temperature levels is supported by the general believe that bud set is induced largely by shortening photoperiod [92] [93], although a positive effect of elevated $\left[\mathrm{CO}_{2}\right]$ has been reported on some tree species including black spruce [24] and Sitka spruce [94]. The earlier bud set in jack pine seedlings by the photoperiod regimes under northward migration is probably associated with their shorter photoperiod in fall time (Table 1).

As expected, the elevated $\left[\mathrm{CO}_{2}\right]$ increased the relative growth rates of root collar diameter $\left(\mathrm{RGR}_{\mathrm{D}}\right)$ and stemvolume $\left(\mathrm{RGR}_{\mathrm{V}}\right.$ ) as well as total seedling biomass (TB). In $\mathrm{C}_{3}$ plants the rate of net $\mathrm{CO}_{2}$ assimilation is not

Table 2. ANOVA P-values for the effects of carbon-dioxide concentration (C), soil temperature (T), photoperiod (P) and their interactions on total days to budburst and bud set, relative growth rate of height, root collar diameter and volume $\left(\mathrm{RGR}_{\mathrm{H}}, \mathrm{RGR}_{\mathrm{D}}\right.$ and $\mathrm{RGR}_{\mathrm{V}}$, respectively), total biomass (M), total leaf area (projected) per seedling (LA), stem mass ratio (SMR), root mass ratio (RMR), leaf mass ratio (LMR), shoot to root mass ratio (SRR), specific leaf area (SLA), specific root length (SRL), specific root surface area (SRA) and root length to leaf area ratio (RLA). Seedlings were grown under two levels of $\left[\mathrm{CO}_{2}\right]$, two levels of soil temperature and three photoperiod regimes.

\begin{tabular}{|c|c|c|c|c|c|c|c|}
\hline \multirow{2}{*}{$\begin{array}{l}\text { Response } \\
\text { variables }\end{array}$} & \multicolumn{7}{|c|}{ Treatment effects } \\
\hline & $\mathrm{C}$ & $\mathrm{T}$ & $\mathrm{P}$ & $\mathrm{C} * \mathrm{~T}$ & $\mathrm{C} * \mathrm{P}$ & $\mathrm{T}^{*} \mathrm{P}$ & $\mathrm{C}^{*} \mathrm{~T}^{*} \mathrm{P}$ \\
\hline Budburst & 0.028 & 0.013 & 0.044 & 0.020 & 0.999 & 0.633 & 0.045 \\
\hline Budset & 0.152 & 0.134 & $<0.001$ & 0.895 & 0.107 & 0.325 & 0.087 \\
\hline $\mathrm{RGR}_{\mathrm{H}}$ & 0.927 & 0.726 & 0.019 & 0.359 & 0.250 & 0.769 & 0.240 \\
\hline $\mathrm{RGR}_{\mathrm{D}}$ & 0.040 & 0.128 & 0.395 & 0.010 & 0.567 & 0.275 & 0.423 \\
\hline $\mathrm{RGR}_{\mathrm{V}}$ & 0.013 & 0.394 & 0.709 & 0.083 & 0.494 & 0.711 & 0.511 \\
\hline M & 0.005 & 0.062 & 0.315 & 0.145 & 0.081 & 0.981 & 0.709 \\
\hline LA & 0.020 & 0.071 & 0.120 & 0.633 & 0.497 & 0.588 & 0.553 \\
\hline SMR & 0.613 & 0.071 & 0.205 & 0.167 & 0.399 & 0.802 & 0.552 \\
\hline RMR & 0.055 & 0.147 & 0.136 & 0.831 & 0.851 & 0.608 & 0.943 \\
\hline LMR & 0.013 & 0.565 & 0.236 & 0.155 & 0.714 & 0.376 & 0.300 \\
\hline SRR & 0.042 & 0.117 & 0.084 & 0.713 & 0.730 & 0.609 & 0.963 \\
\hline SLA & 0.950 & 0.624 & 0.322 & 0.714 & 0.807 & 0.790 & 0.914 \\
\hline SRL & 0.033 & 0.168 & 0.774 & 0.168 & 0.130 & 0.104 & 0.277 \\
\hline SRA & 0.012 & 0.093 & 0.650 & 0.078 & 0.256 & 0.639 & 0.534 \\
\hline RLA & 0.346 & 0.034 & 0.052 & 0.090 & 0.762 & 0.921 & 0.436 \\
\hline
\end{tabular}

Note: Significant effect $(\mathrm{P} \leq 0.05)$ was bold-faced. 
$\mathrm{CO}_{2}$-saturated at the current level of atmospheric $\left[\mathrm{CO}_{2}\right][7]$ and higher $\left[\mathrm{CO}_{2}\right]$ would positively affect growth if nutrients are not limiting (as would be in this study). The enhanced growth by elevated $\left[\mathrm{CO}_{2}\right]$ may also be related to the reductions in dark respiration and earlier budburst and therefore longer growing season [10] [12] [24] [25] [95]-[99]. Similarly, $\mathrm{RGR}_{\mathrm{H}}$ was greater under photoperiod regimes associated with higher latitudes in jack pine seedlings, possibly due to longer hours of photosynthesis. We did not find significant increases of $\mathrm{RGR}_{\mathrm{H}}$ with elevated $\left[\mathrm{CO}_{2}\right]$ and seedling growth with warmer soils, as has been reported by others [25] [26] [37] [100][103]. We speculate that the soil temperature at seed origin is not too low to affect the physiological activities and growth of jack pine seedlings, as indicated by others that soil temperature effect is more species-specific [102] [104] [105].

As found by others [6] [8] [10] [20] [106] [107], elevated [ $\mathrm{CO}_{2}$ ] affected biomass allocation and functional traits of leaf and root in jack pine seedlings such as lower leaf mass ratio (LMR), shoot to root ratio (SRR), specific root length (SRL) and specific root surface area (SRA), even though not all of the treatment effects (e.g., specific leaf area (SLA)) reached the level of significance.

Though the main effects on phenological traits, growth and biomass allocation were mostly significant, interactive effects were generally statistically insignificant in this study with the exception of budburst and RCD. Rather than suggesting the lack of real significant interactions, these results indicate the difficulties in detecting interactive effects when multiple environmental variables are being investigated. As the number of treatment factors increase, the degree of freedom for the error term used to test interactions declines, causing a loss of the capability of the experiment to detect interactive effects. A remedy to the problem will be to increase the sample size. However, such a remedy often faces great logistical challenges. A more practical approach for investigating the interactive effects of multiple factors is yet to be found.

\section{References}

[1] Cleland, E.E., Allen, J.M., Crimmins, T.M., Dunne, J.A., Pau, S., Travers, S.E., Zavaleta, E.S. and Wolkovich, E.M. (2012) Phenological Tracking Enables Positive Species Responses to Climate Change. Ecology, 93, 1765-1771. http://dx.doi.org/10.1890/11-1912.1

[2] Soolanayakanahally, R.Y., Guy, R.D., Silim, S.N. and Song, M. (2013) Timing of Photoperiodic Competency Causes Phenological Mismatch in Balsam Poplar (Populus balsamifera L.). Plant, Cell and Environment, 36, 116-127. http://dx.doi.org/10.1111/j.1365-3040.2012.02560.x

[3] Aitken, S.N., Yeaman, S., Holliday, J.A., Wang, T.L. and Curtis-McLane, S. (2008) Adaptation, Migration or Extirpation: Climate Change Outcomes for Tree Populations. Evolutionary Applications, 1, 95-111. http://dx.doi.org/10.1111/j.1752-4571.2007.00013.x

[4] Bunnell, F.L. and Kremsater, L.L. (2012) Migrating Like a Herd of Cats: Climate Change and Emerging Forests in British Columbia. Journal of Ecosystems and Management, 13, 27-50.

[5] Johnston, M.H., Campagna, M., Gray, P.A., Kope, H.H., Loo, J.A., Ogden, A.E., O’Neill, G.A., Price, D.T. and Williamson, T.B. (2009) Vulnerability of Canada's Tree Species to Climate Change and Management Options for Adaptation: An Overview for Policy Makers and Practitioners. Canadian Council of Forest Ministers. Northern Forestry Centre, 44.

[6] Huang, J.G., Bergeron, Y., Denneler, B., Berninger, F. and Tardif, J. (2007) Response of Forest Trees to Increased Atmospheric $\mathrm{CO}_{2}$. Critical Reviews in Plant Sciences, 26, 265-283. http://dx.doi.org/10.1080/07352680701626978

[7] Lambers, H., Chapin III, F.S. and Thijs, L.P. (2008) Plant Physiological Ecology. 2nd Edition, Springer, New York, $604 \mathrm{p}$.

[8] Lukac, M., Calfapietra, C., Lagomarsino, A. and Loreto, F. (2010) Global Climate Change and Tree Nutrition: Effects of Elevated $\mathrm{CO}_{2}$ and Temperature. Tree Physiology, 30, 1209-1220. http://dx.doi.org/10.1093/treephys/tpq040

[9] Ainsworth, E.A. and Long, S.P. (2005) What Have We Learned from 15 Years of Free-Air $\mathrm{CO}_{2}$ Enrichment (FACE)? A Meta-Analytic Review of the Responses of Photosynthesis, Canopy Properties and Plant Production to Rising $\mathrm{CO}_{2}$. New Phytologist, 165, 351-372. http://dx.doi.org/10.1111/j.1469-8137.2004.01224.X

[10] Curtis, P.S. and Wang, X. (1998) A Meta-Analysis of Elevated $\mathrm{CO}_{2}$ Effects on Woody Plant Mass, Form, and Physiology. Oecologia, 113, 299-313. http://dx.doi.org/10.1007/s004420050381

[11] Idso, K.E. and Edso, S.B. (1994) Plant Responses to Atmospheric $\mathrm{CO}_{2}$ Enrichment in the Face of Environmental Constraints: A Review of the Past 10 Years’ Research. Agricultural and Forest Meteorology, 69, 153-203. http://dx.doi.org/10.1016/0168-1923(94)90025-6

[12] Marfo, J. and Dang, Q.L. (2009) Interactive Effects of Carbon Dioxide Concentration and Light on the Morphological 
and Biomass Characteristics of Black Spruce Seedlings. Botany, 87, 67-77. http://dx.doi.org/10.1139/B08-114

[13] Norby, R.J., Wullschleger, S.D., Gunderson, C.A., Johnson, D.W. and Ceulemans, R. (1999) Tree Responses to Rising $\mathrm{CO}_{2}$ in Field Experiments: Implication for Future Forest. Plant, Cell and Environment, 22, 683-714. http://dx.doi.org/10.1046/j.1365-3040.1999.00391.x

[14] Pregitzer, K.S., King, J.S., Andrew, J.B. and Brown, E. (2000) Responses of Tree Fine Roots to Temperature. New Phytologist, 147, 105-115. http://dx.doi.org/10.1046/j.1469-8137.2000.00689.x

[15] Eamus, D. and Jarvis, P.G. (1989) The Direct Effects of Increase in the Global Atmospheric $\mathrm{CO}_{2}$ Concentration on Natural and Commercial Temperate Trees and Forests. Advances in Ecological Research, 19, 1-55. http://dx.doi.org/10.1016/S0065-2504(08)60156-7

[16] Koch, K.E., Jones, P.H., Avigne, W.T. and Allen, L.H. (1986) Growth and Dry Matter Partitioning and Diurnal Activities of RuBP Carboxylase in Citrus Seedlings Maintained at Two Levels of $\mathrm{CO}_{2}$. Physiologia Plantarum, 67, 477-484. http://dx.doi.org/10.1111/j.1399-3054.1986.tb05766.x

[17] Norby, R.J. and O’Neill, E.G. (1989) Growth Dynamics and Water Use of Seedlings of Quercus alba L. in $\mathrm{CO}_{2}$-Enriched Atmospheres. New Phytologist, 111, 491-500. http://dx.doi.org/10.1111/j.1469-8137.1989.tb00712.x

[18] Pettersson, R., McDonald, A.J.S. and Stadenberg, I. (1993) Response of Small Birch Plants (Betula pendula Roth.) to Elevated $\mathrm{CO}_{2}$ and Nitrogen Supply. Plant, Cell \& Environment, 16, 1115-1121. http://dx.doi.org/10.1111/j.1365-3040.1996.tb02069.x

[19] Samuelson, L.J. and Seiler, J.R. (1993) Interactive Role of Elevated $\mathrm{CO}_{2}$, Nutrient Limitations, and Water Stress in the Growth Responses of Red Spruce Seedlings. Forest Science, 39, 348-358.

[20] Rogers, H.H., Runion, G.B. and Krupa, S.V. (1994) Plant Responses to Atmospheric $\mathrm{CO}_{2}$ Enrichment with Emphasis on Roots and the Rhizosphere. Environmental Pollution, 83, 155-189. http://dx.doi.org/10.1016/0269-7491(94)90034-5

[21] Tingey, D.T., Phillips, D.L. and Johnson, M.G. (2000) Elevated $\mathrm{CO}_{2}$ and Conifer Roots: Effects on Growth, Life Span and Turnover. New Phytologist, 147, 87-103. http://dx.doi.org/10.1046/j.1469-8137.2000.00684.x

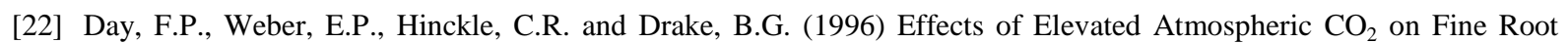
Length and Distribution in an Oak-Palmetto Scrub Ecosystem in Central Florida. Global Change Biology, 2, 143-148. http://dx.doi.org/10.1111/j.1365-2486.1996.tb00059.x

[23] Janssens, I.A., Crookshanks, M., Taylor, G. and Ceulemans, R. (1998) Elevated $\mathrm{CO}_{2}$ Increases Fine Root Production, Respiration, Rhizosphere Respiration and Soil $\mathrm{CO}_{2}$ Efflux in Scots Pine Seedlings. Global Change Biology, 4, 871-878. http://dx.doi.org/10.1046/j.1365-2486.1998.00199.x

[24] Bigras, F.J. and Bertrand, A. (2006) Responses of Piceamariana to Elevated $\mathrm{CO}_{2}$ Concentration during Growth, Cold Hardening and Dehardening: Phenology, Cold Tolerance, Photosynthesis and Growth. Tree Physiology, 26, 875-888. http://dx.doi.org/10.1093/treephys/26.7.875

[25] Ceulemans, R., Jiang, X.N. and Shao, B.Y. (1995) Effects of Elevated Atmospheric $\mathrm{CO}_{2}$ on Growth, Biomass Production and Nitrogen Allocation of Two Populus Clones. Journal of Biogeography, 22, 261-268. http://dx.doi.org/10.2307/2845920

[26] Jach, M.E. and Ceulemans, R. (1999) Effects of Elevated Atmospheric $\mathrm{CO}_{2}$ on Phenology, Growth and Crown Structure of Scots Pine (Pinus sylvestris) Seedlings after Two Years of Exposure in the Field. Tree Physiology, 19, $289-300$. http://dx.doi.org/10.1093/treephys/19.4-5.289

[27] Murray, M.B., Cannell, M.G.R. and Smith, R.I. (1989) Date of Bud Burst of Fifteen Tree Species in Britain Following Climate Warming. Journal of Applied Ecology, 26, 693-700. http://dx.doi.org/10.2307/2404093

[28] Heninger, R.L. and White, D.P. (1974) Tree Seedling Growth at Different Soil Temperatures. Forest Science, 20, 363367.

[29] Lyford, W.H. and Wilson, B.F. (1966) Controlled Growth of Forest Tree Roots: Technique and Application. Harvard Forest Paper 16, p. 12.

[30] Alvarez-Uria, P. and Körner, C. (2007) Low Temperature Limits of Root Growth in Deciduous and Evergreen Temperate Tree Species. Functional Ecology, 21, 211-218. http://dx.doi.org/10.1111/j.1365-2435.2007.01231.x

[31] Cai, T.B. and Dang, Q.L. (2002) Effects of Soil Temperature on Parameters of a Coupled Photosynthesis-Stomatal Conductance Model. Tree Physiology, 22, 819-828. http://dx.doi.org/10.1093/treephys/22.12.819

[32] Camm, E.L. and Harper, G.J. (1991) Temporal Variations in Cold Sensitivity of Root Growth in Cold-Stored White Spruce Seedlings. Tree Physiology, 9, 425-431. http://dx.doi.org/10.1093/treephys/9.3.425

[33] Dang, Q.L. and Cheng, S. (2004) Effects of Soil Temperature on Ecophysiological Traits in Seedlings of Four Boreal Tree Species. Forest Ecology and Management, 194, 379-387. http://dx.doi.org/10.1016/j.foreco.2004.03.004

[34] Landhäusser, S.M., DesRochers, A. and Lieffers, V.J. (2001) A Comparison of Growth and Physiology in Picea 
glauca and Populus tremuloides at Different Soil Temperatures. Canadian Journal of Forest Research, 31, 1922-1929.

[35] Stathers, R.J. and Spittlehouse, D.L. (1990) Forest Soil Temperature Manual. FRDA Report No. 130, British Columbia Ministry of Forests, Victoria.

[36] Grossnickle, S.C. (2000) Ecophysiology of Northern Spruce Species: The performance of Planted Seedlings. NRC Research Press, Ottawa, 409.

[37] Peng, Y.Y. and Dang, Q.L. (2003) Effects of Soil Temperature on Biomass Production and Allocation in Seedlings of Four Boreal Tree Species. Forest Ecology and Management, 180, 1-9. http://dx.doi.org/10.1016/S0378-1127(02)00486-3

[38] Tierney, G., Fahey, T., Groffman, P., Hardy, J., Fitzhugh, R. and Driscoll, C. (2001) Soil Freezing Alters Fine Root Dynamics in A Northern Hardwood Forest. Biogeochemistry, 56, 175-190. http://dx.doi.org/10.1023/A:1013072519889

[39] Ambebe, T.F., Dang, Q.L. and Li, J. (2010) Low Soil Temperature Inhibits the Effects of High Nutrient Supply on Photosynthetic Response to Elevated Carbon Dioxide Concentration in White Birch Seedlings. Tree Physiology, 30, 234-243. http://dx.doi.org/10.1093/treephys/tpp109

[40] Domisch, T., Finér, L., Lehto, T. and Smolander, A. (2002) Effect of Soil Temperature on Nutrient Allocation and Mycorrhizas in Scots Pine Seedlings. Plant and Soil, 239, 173-185. http://dx.doi.org/10.1023/A:1015037127126

[41] Häussling, C.A., Jorn, C.A., Lehmbecker, G., Hecht-Buchholz, C. and Marschner, H. (1988) Ion and Water Uptake in Relation to Root Development in Norway Spruce (Picea abies [L.] Karst.). Journal of Plant Physiology, 133, 486-491. http://dx.doi.org/10.1016/S0176-1617(88)80042-7

[42] Campbell, R.K. and Sugano, A.I. (1975) Phenology of Bud Burst in Douglas-Fir Related to Provenance, Photoperiod, Chilling, and Flushing Temperature. International Journal of Plant Sciences, 136, 290-298. http://dx.doi.org/10.1086/336817

[43] Campbell, R.K. (1979) Genecology of Douglas-Fir in a Watershed in the Oregon Cascades. Ecology, 60, $1036-1050$. http://dx.doi.org/10.2307/1936871

[44] Weiser, C.J. (1970) Cold Resistance and Injury in Woody Plants. Science, 169, 1269-1278. http://dx.doi.org/10.1126/science.169.3952.1269

[45] Hänninen, H. (2006) Climate Warming and the Risk of Frost Damage to Boreal Forest Trees: Identification of Critical Ecophysiological Traits. Tree Physiology, 26, 889-898. http://dx.doi.org/10.1093/treephys/26.7.889

[46] Thomas, B. and Vince-Prue, D. (1997) Photoperiodism in Plants. 2nd Edition, Academic Press, San Diego, 428.

[47] Colombo, S.J., Zhao, S.Y. and Blumwald, E. (1995) Frost Hardiness Gradients in Shoots and Roots of Picea mariana Seedlings. Scandinavian Journal of Forest Research, 10, 32-36. http://dx.doi.org/10.1080/02827589509382864

[48] Fracheboud, Y., Luquez, V., Björkén, L., Sjödin, A., Tuominen, H. and Jansson, S. (2009) The Control of Autumn Senescence in European Aspens. Plant Physiology, 149, 1982-1991. http://dx.doi.org/10.1104/pp.108.133249

[49] Curtis, P.S., Vogel, C.S., Wang, X., Pregistzer, K.S., Zak, D.R., Lussenhop, J., Kubiske, M. and Teeri, J.A. (2000) Gas Exchange, Leaf Nitrogen, and Growth Efficiency of Populus tremuloides in a $\mathrm{CO}_{2}$-Enriched Atmosphere. Ecological Applications, 10, 3-17.

[50] Nowak, R.S., Ellsworth, D.S. and Smith, S.D. (2004) Functional Responses of Plants to Elevated Atmospheric $\mathrm{CO}_{2}-$ Do Photosynthetic and Productivity Data from FACE Experiments Support Early Predictions? New Phytologist, 162, 253-280. http://dx.doi.org/10.1111/j.1469-8137.2004.01033.x

[51] Allen, S.G., Idso, S.B. and Kimball, B.A. (1990) Interactive Effects of $\mathrm{CO}_{2}$ and Environment on Net Photosynthesis of Water-Lily. Agriculture, Ecosystems \& Environment, 30, 81-88. http://dx.doi.org/10.1016/0167-8809(90)90185-G

[52] Mishra, R.S., Abdin, M.Z. and Uprety, D.C. (1999) Interactive Effects of Elevated $\mathrm{CO}_{2}$ and Moisture Stress on the Photosynthesis, Water Relation and Growth of Brassica Species. Journal of Agronomy \& Crop Science, 182, 223-229. http://dx.doi.org/10.1046/j.1439-037x.1999.00294.x

[53] Robredo, A., Pérez-López, U., Sainz, H., de la Maza, B., González-Moro, M.L., Mena-Petite, A. and Muñoz-Rueda, A. (2007) Elevated $\mathrm{CO}_{2}$ Alleviates the Impact of Drought on Barley Improving Water Status by Lowering Stomatal Conductance and Delaying Its Effects on Photosynthesis. Environmental and Experimental Botany, 59, 252-263. http://dx.doi.org/10.1016/j.envexpbot.2006.01.001

[54] Zebian, K.J. and Reekie, E.G. (1998) The Interactive Effects of Atmospheric Carbon Dioxide and Light on Stem Elongation in Seedlings of Four Species. Annals of Botany, 81, 185-193. http://dx.doi.org/10.1006/anbo.1997.0528

[55] Cantin, D., Tremblay, M.F., Lechowicz, M.J. and Potvin, C. (1997) Effects of $\mathrm{CO}_{2}$ Enrichment, Elevated Temperature, and Nitrogen Availability on the Growth and Gas Exchange of Different Families of Jack Pine Seedlings. Canadian Journal of Forest Research, 27, 510-520. 
[56] DeLucia, E.H. and Smith, W.K. (1987) Air and Soil Temperature Limitations on Photosynthesis in Engelmann Spruce during Summer. Canadian Journal of Forest Research, 17, 527-533. http://dx.doi.org/10.1139/x87-088

[57] Fraser, D.A. (1962) Growth of Spruce Seedlings under Long Photoperiods. Canada Department of Forestry, Forest Research Branch, Technical Note No. 114.

[58] Li, J., Dang, Q.L. and Man, R. (2015) Photoperiod and Nitrogen Supply Limit the Scope of Northward Migration and Seed Transfer of Black Spruce in a Future Climate Associated with Doubled Atmospheric $\mathrm{CO}_{2}$ Concentration. American Journal of Plant Sciences, 6, 189-200. http://dx.doi.org/10.4236/ajps.2015.61022

[59] Way, D.A. and Sage, R.F. (2008) Thermal Acclimation of Photosynthesis in Black Spruce [Picea mariana (Mill.) B.S.P.]. Plant, Cell and Environment, 31, 1250-1262. http://dx.doi.org/10.1111/j.1365-3040.2008.01842.x

[60] Way, D.A. and Sage, R.F. (2008) Elevated Growth Temperatures Reduce the Carbon Gain of Black Spruce [Picea mariana (Mill.) B.S.P.]. Global Change Biology, 14, 624-636. http://dx.doi.org/10.1111/j.1365-2486.2007.01513.x

[61] Fowells, H.A. (1965) Silvics of Forest Trees of the United States. US Department of Agriculture, Agriculture Handbook No. 271.

[62] Forestry Canada (1992) Selected Forestry Statistics Canada 1991. Forestry Canada, Policy and Economics Directorate, Ottawa. Information Report E-X-46, 231 p.

[63] OMNR (1991) Statistics 1989-1990. Queen’s Printer for Ontario, Toronto, 106 p.

[64] McKenney, D.W., Pedlar, J.H., Lawrence, K.E.V.I., Campbell, K. and Hutchinson, M.F. (2007) Potential Impacts of Climate Change on the Distribution of North American Trees. BioScience, 57, 939-948. http://dx.doi.org/10.1641/B571106

[65] McKenney, D.W., Pedlar, J.H., Rood, R.B. and Price, D.A.V.I. (2011) Revisiting Projected Shifts in the Climate Envelopes of North American Trees Using Updated General Circulation Models. Global Change Biology, 17, $2720-2730$. http://dx.doi.org/10.1111/j.1365-2486.2011.02413.x

[66] Pearson, R.G. and Dawson, T.P. (2003) Predicting the Impacts of Climate Change on the Distribution of Species: Are Bioclimate Envelope Models Useful? Global Ecology and Biogeography, 12, 361-371. http://dx.doi.org/10.1046/j.1466-822X.2003.00042.x

[67] Tjoelker, M.G., Oleksyn, J. and Reich, P.B. (1998) Seedlings of Five Boreal Tree Species Differ in Acclimation of Net Photosynthesis to Elevated $\mathrm{CO}_{2}$ and Temperature. Tree Physiology, 18, 715-726. http://dx.doi.org/10.1093/treephys/18.11.715

[68] Cheng, S., Dang, Q.L. and Cai, T.B. (2000) A Soil Temperature Control System for Ecological Research in Greenhouses. Journal of Forest Research, 5, 205-208. http://dx.doi.org/10.1007/BF02762403

[69] Scarratt, J.B. (1986) An Evaluation of Some Commercial Soluble Fertilizers for Culture of Jack Pine Container Stock. Canadian Forestry Service, Great Lakes Forestry Centre, Sault Ste. Marie, Ontario, Information Report O-X-377, 21 p.

[70] van den Driessche, R. (1992) Absolute and Relative Growth of Douglas-Fir Seedlings of Different Sizes. Tree Physiology, 10, 141-152. http://dx.doi.org/10.1093/treephys/10.2.141

[71] R Core Team (2015) R: A Language and Environment for Statistical Computing. R Foundation for Statistical Computing, Vienna, Austria. http://www.R-project.org/

[72] Basler, D. and Korner, C. (2012) Photoperiod Sensitivity of Bud Burst in 14 Temperate Forest Tree Species. Agricultural and Forest Meteorology, 165, 73-81. http://dx.doi.org/10.1016/j.agrformet.2012.06.001

[73] Heide, O.M. (1993) Daylength and Thermal Time Responses of Bud Burst during Dormancy Release in Some Northern Deciduous Trees. Physiologia Plantarum, 88, 531-540. http://dx.doi.org/10.1111/j.1399-3054.1993.tb01368.x

[74] Heide, O.M. (1993) Dormancy Release in Beech Buds (Fagus sylvatica) Requires Both Chilling and Long Days. Physiologia Plantarum, 89, 187-191. http://dx.doi.org/10.1111/j.1399-3054.1993.tb01804.x

[75] Körner, C. and Basler, D. (2010) Phenology under Global Warming. Science, 327, 1461-1462. http://dx.doi.org/10.1126/science.1186473

[76] Laube, J., Sparks, T.H., Estrella, N., Höfler, J., Ankerst, D.P. and Menzel, A. (2014) Chilling Outweighs Photoperiod in Preventing Precocious Spring Development. Global Change Biology, 20, 170-182. http://dx.doi.org/10.1111/gcb.12360

[77] Myking, T. and Heide, O.M. (1995) Dormancy Release and Chilling Requirement of Buds of Latitudinal Ecotypes of Betula pendula and B. pubescens. Tree Physiology, 15, 697-704. http://dx.doi.org/10.1093/treephys/15.11.697

[78] Partanen, J., Koski, V. and Hanninen, H. (1998) Effects of Photoperiod and Temperature on the Timing of Bud Burst in Norway Spruce (Picea abies). Tree Physiology, 18, 811-816. http://dx.doi.org/10.1093/treephys/18.12.811

[79] Zohner, C.M. and Renner, S.S. (2014) Common Garden Comparison of the Leaf-Out Phenology of Woody Species from Different Native Climates, Combined with Herbarium Records Forecasts Long-Term Change. Ecology Letters, 17, 
1016-1025. http://dx.doi.org/10.1111/ele.12308

[80] Zohner, C.M. and Renner, S.S. (2015) Perception of Photoperiod in Individual Buds of Mature Trees Regulates Leaf-Out. New Phytologist, 208, 1023-1030. http://dx.doi.org/10.1111/nph.13510

[81] Jach, M.E., Ceulemans, R. and Murray, M.B. (2001) Impacts of Greenhouse Gases on the Phenology of Forest Trees. In: Karnosky, D.F., Ceulemans, R., Scarascia-Mugnozza, G.E. and Innes, J.L., Eds., The Impact of Carbon Dioxide and Other Greenhouse Gases on Forest Ecosystems, CABI Publishing, CAB International, Wallingford, Oxford, 193235. http://dx.doi.org/10.1079/9780851995519.0193

[82] Slaney, M., Wallin, G., Medhurst, J. and Linder, S. (2007) Impact of Elevated Carbon Dioxide Concentration and Temperature on Bud Burst and Shoot Growth of Boreal Norway Spruce. Tree Physiology, 27, 301-312. http://dx.doi.org/10.1093/treephys/27.2.301

[83] Apple, M.E., Lucash, M.S., Olszyk, D.M. and Tingey, D.T. (1998) Morphogenesis of Douglas Fir Buds Is Altered at Elevated Temperature but Not at Elevated $\mathrm{CO}_{2}$. Environmental and Experimental Botany, 40, 159-172. http://dx.doi.org/10.1016/S0098-8472(98)00031-8

[84] Olszyk, D., Wise, C., VanEss, E., Apple, M. and Tingey, D. (1998) Phenology and Growth of Shoots, Needles, and Buds of Douglas-Fir Seedlings with Elevated $\mathrm{CO}_{2}$ and (or) Temperature. Canadian Journal of Botany, 76, 1991-2001.

[85] Roberntz, P. (1999) Effects of Long-Term $\mathrm{CO}_{2}$ Enrichment and Nutrient Availability in Norway Spruce. I. Phenology and Morphology of Branches. Trees, 18, 188-198. http://dx.doi.org/10.1007/pl00009750

[86] Bergh, J. and Linder, S. (1999) Effects of Soil Warming during Spring on Photosynthetic Recovery in Boreal Norway Spruce Stands. Global Change Biology, 5, 245-253. http://dx.doi.org/10.1046/j.1365-2486.1999.00205.x

[87] Domisch, T., Finer, L. and Lehto, T. (2001) Effects of Soil Temperature on Biomass and Carbohydrate Allocation in Scots Pine (Pinus sylvestris) Seedlings at the Beginning of the Growing Season. Tree Physiology, 21, 465-472. http://dx.doi.org/10.1093/treephys/21.7.465

[88] Vapaavuori, E.M., Rikala, R. and Ryyppo, A. (1992) Effects of Root Temperature on Growth and Photosynthesis in Conifer Seedlings during Shoot Elongation. Tree Physiology, 10, 217-230. http://dx.doi.org/10.1093/treephys/10.3.217

[89] Lyr, H. and Garbe, V. (1995) Influence of Root Temperature on Growth of Pinus sylvestris, Fagus sylvatica, Tilia cordata and Quercus robur. Trees, 9, 220-223. http://dx.doi.org/10.1007/BF00195276

[90] Basler, D. and Korner, C. (2014) Photoperiod and Temperature Responses of Bud Swelling and Bud Burst in Four Temperate Forest Tree Species. Tree Physiology, 34, 377-388. http://dx.doi.org/10.1093/treephys/tpu021

[91] Hänninen, H. (1990) Modelling Bud Dormancy Release in Trees from Cool and Temperate Regions. Acta Forestalia Fennica, 213, 1-47.

[92] Dalen, L.S. (1998) Elevated $\mathrm{CO}_{2}$ and Development of Frost Hardiness in Norway Spruce (Picea abies (L.) Karst). Thesis, Agricultural University of Norway.

[93] Centritto, M., Lee, H.S.J. and Jarvis, P.G. (1999) Long-Term Effects of Elevated Carbon Dioxide Concentration and Provenance on Four Clones of Sitka Spruce (Picea sitchensis). I. Plant Growth, Allocation and Ontogeny. Tree Physiology, 19, 799-806. http://dx.doi.org/10.1093/treephys/19.12.799

[94] Murray, M.B., Smith, R.I., Leith, I.D., Fowler, D., Lee, H.S.J., Friend, A.D. and Jarvis, P.G. (1994) Effects of Elevated $\mathrm{CO}_{2}$, Nutrition and Climatic Warming on Bud Phenology in Sitka Spruce (Picea sitchensis) and Their Impact on the Risk of Frost Damage. Tree Physiology, 14, 691-706. http://dx.doi.org/10.1093/treephys/14.7-8-9.691

[95] Surano, K.A., Daley, P.F., Houpis, J.L.J., Shinn, J.H., Helms, J.A., Palassou, R.J. and Costella, M.P. (1986) Growth and Physiological Responses of Pinus ponderosa Dougl ex P. Laws. to Long-Term Elevated $\mathrm{CO}_{2}$ Concentrations. Tree Physiology, 2, 243-259. http://dx.doi.org/10.1093/treephys/2.1-2-3.243

[96] Guehl, J.M., Picon, C., Aussenac, G. and Gross, P. (1994) Interactive Effects of Elevated $\mathrm{CO}_{2}$ and Soil Drought on Growth and Transpiration Efficiency and Its Determinants in Two European Forest Tree Species. Tree Physiology, 14, 707-724. http://dx.doi.org/10.1093/treephys/14.7-8-9.707

[97] Johnsen, K.H. and Seiler, J.R. (1996) Growth, Shoot Phenology and Physiology of Diverse Seed Sources of Black Spruce: I. Seedling Responses to Varied Atmospheric $\mathrm{CO}_{2}$ Concentrations and Photoperiods. Tree Physiology, 16, 367373. http://dx.doi.org/10.1093/treephys/16.3.367

[98] DeLucia, E.H. and Thomas, R.B. (2000) Photosynthetic Responses to $\mathrm{CO}_{2}$ Enrichment of Four Hardwood Species in a Forest Understory. Oecologia, 122, 11-19. http://dx.doi.org/10.1007/PL00008827

[99] Zhang, S. and Dang, Q.L. (2006) Effects of Carbon Dioxide and Nutrition on Photosynthetic Functions of White Birch Seedlings. Tree Physiology, 26, 1457-1467. http://dx.doi.org/10.1093/treephys/26.11.1457

[100] Pushnik, J.C., Demaree, R.S., Houpis, J.L.J., Flory, W.B., Bauer, S.M. and Anderson, P.D. (1995) The Effect of Elevated Carbon Dioxide on a Sierra-Nevadan Dominant Species: Pinus ponderosa. Journal of Biogeography, 22, 249254. http://dx.doi.org/10.2307/2845918 
[101] Ambebe, T.F., Danyagri, G. and Dang, Q.L. (2013) Low Soil Temperature Inhibits the Stimulatory Effect of Elevated $\left[\mathrm{CO}_{2}\right]$ on Height and Biomass Accumulation of White Birch Seedlings Grown under Three Non-Limiting Phosphorus Conditions. Nordic Journal of Botany, 31, 239-246. http://dx.doi.org/10.1111/j.1756-1051.2012.01211.X

[102] Dawes, M.A., Hagedorn, F., Zumbrunn, T., Handa, I.T., Hättenschwiler, S., Wipf, S. and Rixen, C. (2011) Growth and Community Responses of Alpine Dwarf Shrubs to in Situ $\mathrm{CO}_{2}$ Enrichment and Soil Warming. New Phytologist, 191, 806-818. http://dx.doi.org/10.1111/j.1469-8137.2011.03722.x

[103] Walker, M.D., Wahren, C.H., Hollister, R.D., Henry, G.H.R., Ahlquist, L.E., Alatalo, J.M., Bret-Harte, M.S., Calef, M.P., Callaghan, T.V., Carroll, A.B., et al. (2006) Plant Community Responses to Experimental Warming across the Tundra Biome. Proceedings of the National Academy of Sciences of the United States of America, 103, 1342-1346. http://dx.doi.org/10.1073/pnas.0503198103

[104] Butler, S.M., Melillo, J.M., Johnson, J.E., Mohan, J., Steudler, P.A., Lux, H., Burrows, E., Smith, R.M., Vario, C.L., Scott, L., Hill, T.D., Aponte, N. and Bowles, F. (2012) Soil Warming Alters Nitrogen Cycling in a New England Forest: Implications for Ecosystem Function and Structure. Oecologia, 168, 819-828. http://dx.doi.org/10.1007/s00442-011-2133-7

[105] Melillo, J.M., Butler, S., Johnson, J., Mohan, J., Steudler, P., Lux, H., Burrows, E., Bowles, F., Smith, R., Scott, L., Vario, C., Hill, T., Burton, A., Zhou, Y.M. and Tang, J. (2011) Soil Warming, Carbon-Nitrogen Interactions, and Forest Carbon Budgets. Proceedings of the National Academy of Sciences of the United States of America, 108, 95089512. http://dx.doi.org/10.1073/pnas.1018189108

[106] Zhang, S., Dang, Q.L. and Yü, X. (2006) Nutrient and $\left[\mathrm{CO}_{2}\right]$ Elevation Had Synergistic Effects on Biomass Production but Not on Biomass Allocation of White Birch Seedlings. Forest Ecology and Management, 234, 238-244. http://dx.doi.org/10.1016/j.foreco.2006.07.017

[107] Cao, B., Dang, Q.L., Yü, X. and Zhang, S. (2008) Effects of $\left[\mathrm{CO}_{2}\right]$ and Nitrogen on Morphological and Biomass Traits of White Birch (Betula papyrifera) Seedlings. Forest Ecology and Management, 254, 217-224. http://dx.doi.org/10.1016/j.foreco.2007.08.002 